\title{
Mariusz Kudełko
}

AGH University of Science and Technology

e-mail: mkudelko@zarz.agh.edu.pl

ORCID: 0000-0002-4651-3165

\section{EFFICIENCY OF THE EMISSIONS \\ TRADING SCHEME - A THEORETICAL APPROACH}

\section{EFEKTYWNOŚĆ HANDLU PODEJŚCIE TEORETYCZNE}

DOI: 10.15611/pn.2019.9.07

JEL Classification: P18, Q47, Q57

\begin{abstract}
Summary: The purpose of the article is to indicate the most important feature of the emissions trading system - efficiency - which was the basis for the proposed and currently implemented legal solutions for environmental protection actions. The main reasons for the discrepancies in environmental and economic policies are described. The most important of which are the unequal treatment of the own costs of energy companies and the external costs caused by the emissions of the main pollutants. This causes incorrect investment decisions (allocation) made by the energy producers. The conditions under which the emissions trading system fulfil the criterion of allocation and cost efficiency are given. The analysis of some features that are the essence of this instrument creates the premise for a better understanding of its operation. The negative opinions formulated, also in Poland, emerge mainly from the opinions about this instrument, focusing only on its negative impact on energy prices increases, but also the practice of the EU ETS, which is largely inconsistent with its original assumptions.
\end{abstract}

Keywords: emissions trading system, energy sector, allocation and cost efficiency.

Streszczenie: Celem artykułu jest wskazanie najważniejszej cechy handlu uprawnianiami zbywalnymi - efektywności, która stanowiła fundament dla proponowanych i realizowanych obecnie rozwiązań prawnych w ochronie środowiska. Wskazano główne powody rozbieżności polityki środowiskowej i ekonomicznej. Do najważniejszych należy zaliczyć niejednakowe traktowanie prywatnych kosztów przedsiębiorstw energetycznych i kosztów zewnętrznych powodowanych emisją zanieczyszczeń gazowych. Powoduje to podejmowanie błędnych decyzji inwestycyjnych (alokacyjnych) w sektorze energetycznym. Podano, w jakich warunkach handel uprawnieniami zbywalnymi spełnia warunek efektywności alokacyjnej, a w jakich efektywności kosztowej. Przeprowadzona analiza pewnych cech, które stanowią istotę funkcjonowania tego instrumentu, stwarza przesłanki do lepszego zrozumienia jego działania.

Słowa kluczowe: handel uprawnieniami zbywalnymi, efektywność alokacyjna i kosztowa, sektor energetyczny. 


\section{Introduction}

Environmental policy has been one of the priorities of developed countries for many years. The European Union is a good example of the intense actions undertaken in various areas of the adverse human impact on the environment. They are not always perceived as effective measures, and their efficiency is often questioned. An example of this is the European emissions trading system for $\mathrm{CO}_{2}$ (EU ETS), implemented with varying degrees of success - since 2005. It is one of the instruments included in the so-called climate package, aimed at counteracting the global climate change. The primary goal of the EU ETS is to reduce $\mathrm{CO}_{2}$ emissions, the main gas responsible for the formation of the greenhouse gas effect.

The literature describing the functioning and assessment of this system is numerous. It deals with such issues as the fundamentals of the instrument's operation, including its advantage - analysed from the theoretical side - over other solutions. The classic items include those that perceive this instrument in contrast to other legal solutions, such as [Opschoor, Vos 1989; Pearce, Turner 1990; Tietenberg 1991]. There are many publications concerning the practice of the ETS system, along with an assessment of its effectiveness or efficiency, including [Egenhofer et al. 2011; Abrell, Ndoye Faye, Zachmann 2011; Clo 2009; Ellerman, Convery, Perthuis 2010; Grubb et al. 2012; Laing et al., 2013; Villoria-Sáeza et al. 2016; Faure, Peeters 2008; Martin et al. 2012]. As the EU ETS has a huge impact on the economy, there are many publications regarding its impact on the energy sectors of individual countries [Hoffmann 2007; Linares et al. 2006; De Bruyn et al. 2008; Lund 2007; Kirat et al. 2011; Conga et al. 2010; Bonentia et al. 2013; Rogge, Hoffmann 2010]. The most important are the model approaches indicating the economic or social effects of these solutions [The impact of a $\mathrm{CO}_{2} \ldots$ 2016; Thema et al. 2013; Alberola, Chevallier, Chèze 2009].

In studying this problem, one can see a certain conflict related to the efficiency properties of this instrument and its actual working, so very different from the original assumptions, and thus strongly criticized by many economic organizations and practitioners as an ineffective and inefficient tool for implementing the EU climate policy.

Hence the aim of the article is to highlight the most important feature of this instrument, efficiency, which was the basis for proposed and currently implemented legal solutions. The purpose is to at least partly verify the opinions and assessments formulated, also in Poland, about this instrument, focusing only on its negative impact on energy prices increases. In addition, the indication of some features that are the core of this instrument creates the grounds for better understanding of how it works. The article does not assess the practice of the ETS system as, in the author's opinion, it is largely inconsistent with the theoretical assumptions, including desired features such as simplicity. The literature cited above takes up this subject in a very detailed way. 


\section{Negative external effects and economic efficiency}

Negative external effects arise when the action of one person creates costs for other people, who are not taken into account by that person. A typical example of such a situation is the market of energy producers, where - due to the environmental pollution caused by energy production - this type of allocation distortion occurs. In this case the market prices do not reflect all of the economic costs associated with the production of a given good. More precisely, the marginal cost of energy production is not equal to its marginal benefits, because it does not take into account all the external costs arising during the production process. This means the overproduction of energy or its incorrect structure and, as a consequence, the excessive degradation of the environment and the negative human health effects. Society as a whole suffers from this in the sense of the decrease of social welfare.

The indicated market failures justify the state's policy intervention aimed at eliminating this type of allocation distortion. Such a policy is defined as environmental policy and should be consistent with the general economic policy, both in terms of objectives and tools. Unfortunately, economic and environmental goals in many cases are identified as separable or at least interfering with each other. It should be clearly stated that this is a wrong conclusion, resulting from the misunderstanding of the fact that the adverse externalities caused by environmental pollution from an economic point of view are just as important as the costs of the inputs involved in the production process. Secondly, the inequality of the financial burden taken by the parties of environmental conflict (the "victims" and "polluters") and their different bargaining power (economic lobbies) affect the government's incorrect economic decisions. Moreover, the existence of negative externalities is questioned as well (the controversies about the human impact on the greenhouse effect as an example) or in a gentle form - their correct valuation (e.g. health effects caused by smog ${ }^{1}$ ). All of this results in the rejection of optimal solutions or their bad design and wrong implementation. A good example seems to be too many instruments for climate protection policy in the EU or the incorrect rates of environmental fees in Poland. The indicated problems do not exhaust all of the reasons for the discrepancies in environmental and economic policy, nevertheless they specify the most important guidelines of "improvements" of the "regulator" action.

The reasons and some effects of allocation distortions shown above are the main premise of the use of economic instruments (including the emissions trading system) allowing - at least in theory - to eliminate these inefficiencies. Importantly, this does not mean that all of the negative externalities should be eliminated, but only part of them to achieve their optimal level. This in turn means designing a tool that allows action to be taken only to a certain degree for the partial, economically justified limitation of producers activity.

${ }^{1}$ Although ETS does not solve the problem of smog, this is a good example of how important is the proper design of economic instruments to internalize external costs. 


\section{Efficiency of the emissions trading system}

Efficiency can be defined in the broader context of the so-called economic efficiency (optimal allocation) and the narrower perspective, i.e. cost-effectiveness. As indicated earlier, the condition of achieving allocation efficiency requires equalizing the marginal social cost of production with marginal utility (benefits). This, in turn, requires a proper valuation of the external costs caused by environmental pollution. This valuation is crucial to determine the level of the optimal tax rate (an instrument based on the so-called Pigou tax) or the optimal scale of environmental impact (an instrument based on the emissions trading system). Both the first and the second method, if only the correct external cost valuation has been assessed, are a solution ensuring the achievement of allocation efficiency. ${ }^{2}$

Thus the main assumption of the emissions trading system is to determine the optimal total level of emissions, lower than the existing one as a rule. The authorities (regulator) issue and distribute among the enterprises appropriate allowances covering this level, which can be traded on the market. The shortage of allowances in relation to the actual emission leads to the formation of their market price corresponding to the point of intersection of demand and supply curves for allowances. Producers have the following methods to adapt to this situation: 1) reduction of production, and consequently the emission of pollutants (which causes the loss of part of their profits), 2) taking measures to reduce pollution (technology renewal, change of production structure, new low-emission technologies), 3) purchase of allowances on the market. The strategy they choose depends on their own economic valuation of the available solutions. Leaving companies free to choose the adjustment method is the essence of a less restrictive efficiency definition, referred to as cost-effectiveness. Thus the emissions trading system has an advantage over other solutions, because it guarantees achieving the environmental goal (optimal or suboptimal) at a lower cost.

The following figures illustrate the two discussed cases of achieving allocation efficiency. Figure 1 shows the method of determining the optimal level of production, and consequently the desired emission target on a single market, e.g. energy producers. The supply function $S p$ reflects the marginal costs of energy producers. The demand function $D$ informs about the willingness of consumers to purchase their product (electricity). The balance in this market are the $Q p$ production level and the $P p$ price. However, since energy production is accompanied by adverse external effects (the vertical distance between $S s$ and $S p$ represents marginal external costs ${ }^{3}$ ), then the social marginal cost of production is described by the $S s$ curve. The optimal condition here requires a reduction in total production (and thus in emission of pollutants) to the level of $Q s$ at the price of $P S$.

${ }^{2}$ More can be found in the classic literature, such as: [Weitzman 1974; Tietenberg 1991; Baumol, Oates 1988; Helm 2005].

${ }^{3}$ Assumption with a fixed marginal external cost is not necessary, this cost may increase (together with the concentration of pollution, their harmfulness increases). 


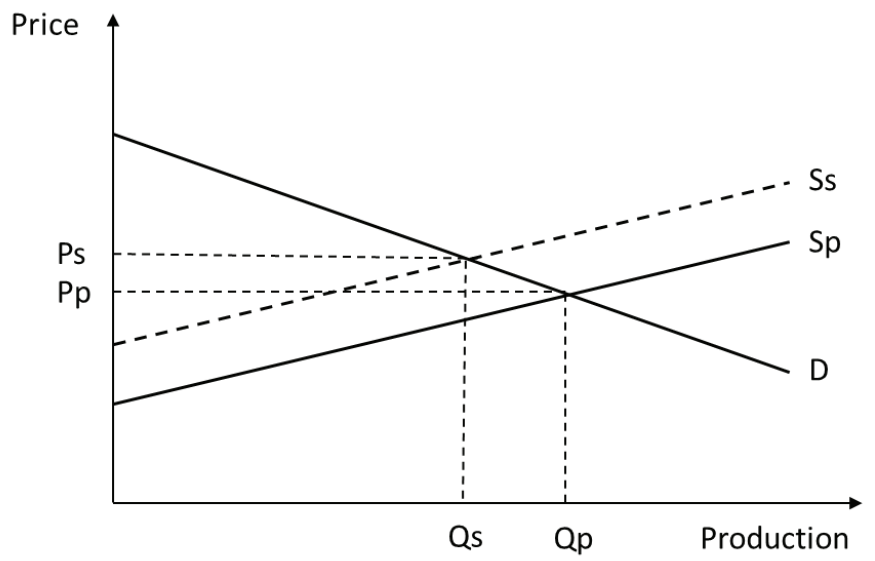

Fig. 1. Optimum level of production (pollution) in a single market

Source: own study.

This objective (emissions level) is the basis to set the total amount of marketable allowances on this market and it can be achieved by reducing energy production or by technical and/or structural reduction of pollutant emissions (Figure 2). The step-up curve represents the emission reduction technologies ranked in terms of marginal costs, which can be technically implemented in industry. The $K z$ function is the marginal external cost caused by pollutant emissions, in this case constant, and the initial total emission level is Ep. The optimum condition requires that reduction measures should be taken until the marginal reduction costs are equated with the marginal external cost, i.e. to the Eo emission level. Some of the technologies are effective (to the left of point $E o$ ), but others should not be implemented because they are too expensive compared to the negative effects (to the right of point $E o$ ). Neither a smaller nor a larger level of emissions reduction is an effective solution. If only these technological options are available, this method of determining the optimal level of pollutant emissions is a solution guaranteeing compliance with the optimum conditions. Importantly, the emissions trading system will be economically efficient, and not only cost-effective, if the total level of marketable allowances Eo will be issued.

This is not an easy task, because the authorities have a serious problem with the lack of information, both in terms of the types and costs of emissions reduction alternatives (difficult to estimate), as well as the negative effects caused by air pollution (hard to define and estimate). For example, when for these reasons the first ones are overestimated (Figure 3) and the second ones underestimated (Figure 4), then the environmental goal is established inappropriately and the emissions trading system is too weak (issuing $\mathrm{EO}_{2}$ instead of $E o_{1}$ allowances), otherwise, the system is too restrictive. 


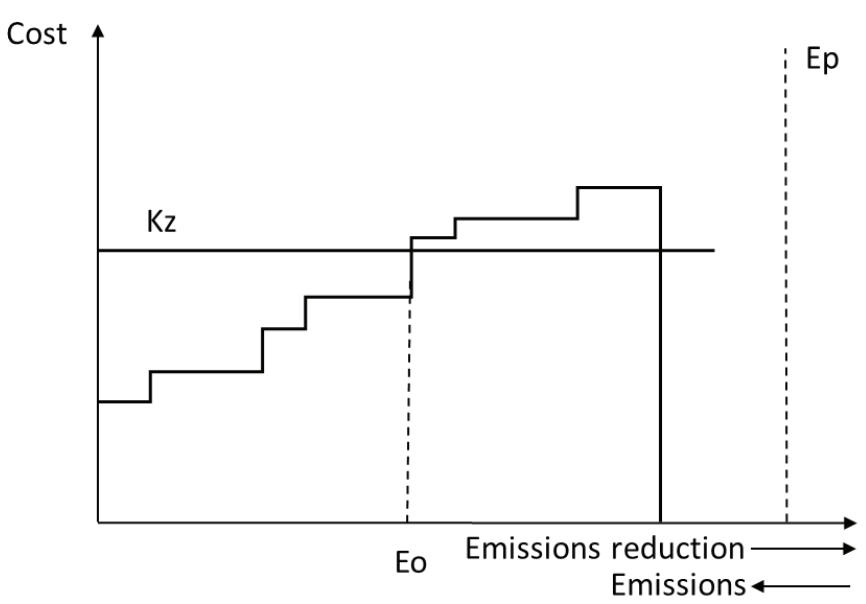

Fig. 2. Optimum level of emissions reduction in a single market

Source: own study.

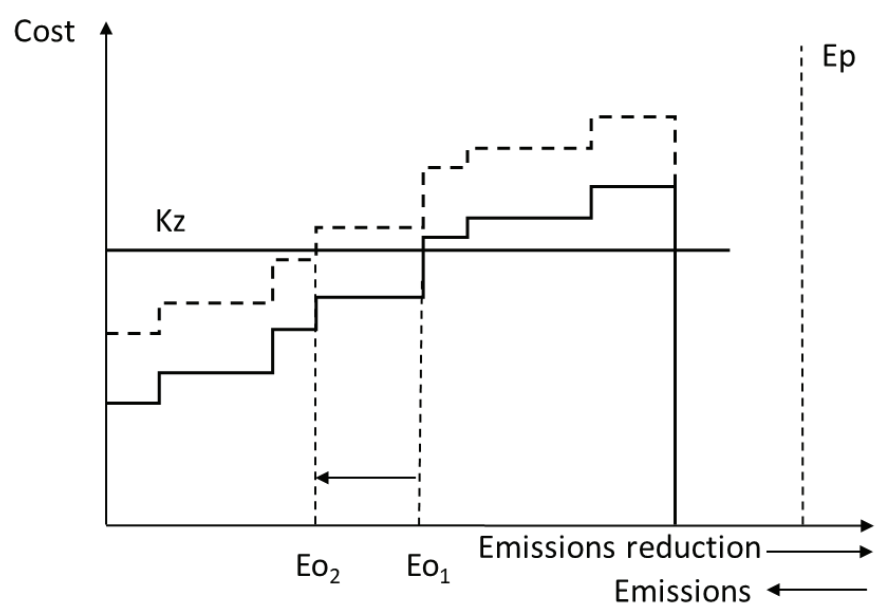

Fig. 3. Incorrect estimation of the costs of emissions reduction

Source: own study.

In such cases, although the system does not meet economic efficiency, it may still be cost-effective, which means that the emissions target (even set incorrectly) will be achieved at the lowest cost. The explanation of this is as follows: the typical solution, called "command and control", is an obligation to limit the emission of pollutants by a percentage value by all producers (optimal or not). An alternative is to give freedom to producers in choosing the adaptation activities. The authorities issue a total quantity of emission allowances (less by the same percentage as in 


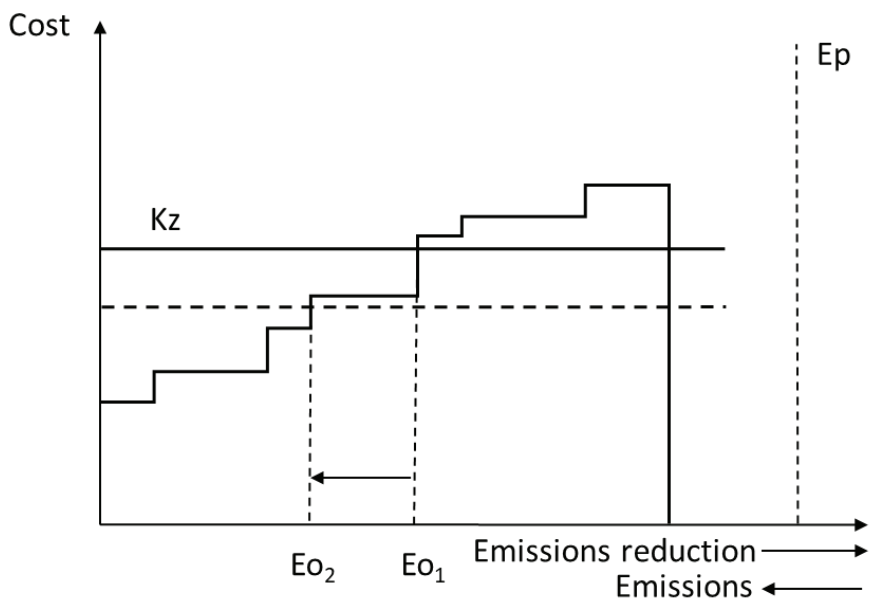

Fig. 4. Incorrect estimation of the external costs of emissions

Source: own study.

"command and control" instrument) and allocate them (in the appropriate share, free or not) to the companies that can trade them. Producers can emit in a specified period of time only a quantity of the pollutants covered by the possessed allowances. The emission of more pollutants requires the purchase of allowances from another participant of the system or undertaking emission-reducing measures on their own [Kudełko 2011]. In this case, the company has the freedom to choose a strategy of reducing pollution or buying allowances. If the price of the allowance is higher than its cost of emissions' reduction, there is an economic incentive to reduce emissions by what is required and sell the surplus on the market. Otherwise, a better solution is to buy allowances from the companies that offer them. As a result, that mechanism encourages actions to lower emissions where the reductions are cheapest. Figure 5 illustrates this mechanism and the benefits of trading.

The figure shows (part "a") companies that differ in the costs of emissions re-emission; for simplicity the same reduction potential is assumed. In the "command and control" system (part "b") all of them must make a reduction by a certain level (e.g. by half, as in the figure), which means the total cost of reduction of the shaded area. In the trading system (part "c"), the emissions reduction is made by the companies with costs lower than the market price of the allowance, e.g. $P u$, and thus the surplus of allowances can be sold to producers for which the purchase of allowances is a cheaper strategy than their own reduction. In both cases, the amount of emissions reduction achieved is the same. However, the cost of this solution, marked by the shaded area, is lower than in the previous case (part "d", costs avoided are marked in black). What is important, is that the benefits are mutual, and thus the tool meets the cost effectiveness condition. 

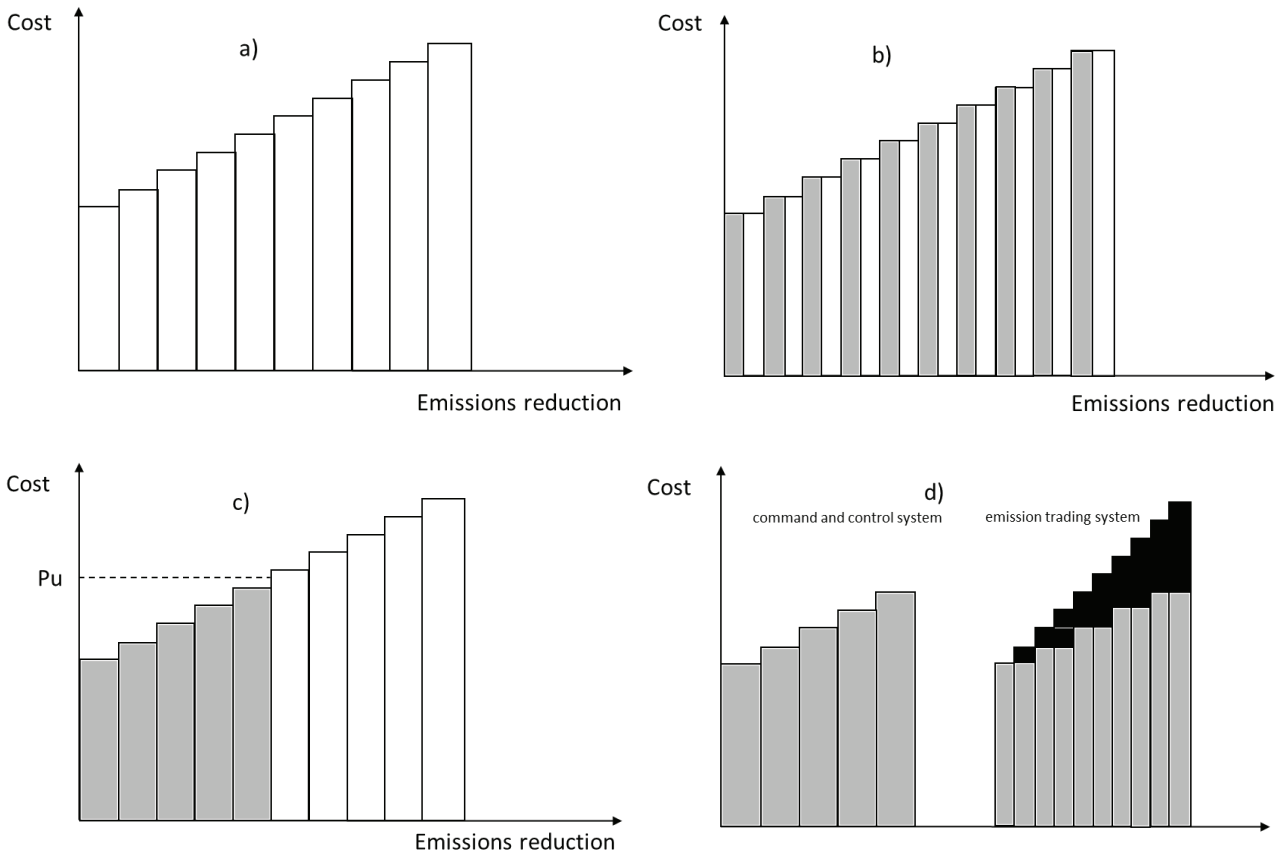

Fig. 5. Benefits from emissions trading system

Source: own study.

It should be strongly emphasized that if the emissions reduction costs of producers (participants of the system) are not diversified, then this instrument loses its properties. This is reflected in removing the avoided emissions reduction costs (Figure 5 "d"). In this case it does not matter which instrument is used, the environmental effect is obtained at the same cost. This is reflected in the practice of environmental policy, where for "standard" technologies for environmental protection and in cases of equal of labour costs, "inflexible" solutions are successfully implemented. In that case, as soon as the cost of avoiding pollution is lower than its benefit, then it is also an effective strategy.

\section{Conclusions}

Despite the fact that the environmental awareness of people is still growing (which is exemplified by the anti-smog action carried out in Poland), one can still encounter a number of difficulties in the correct assessment of the economic consequences of the environmental policy. This particularly applies to the energy sector, where its great economic importance is contrasted with the environmental threats it poses. 
It seems that one of the most significant reasons for this comes from the incorrect assumptions underlying the cost-benefit analysis of achieving the environmental policy objectives. It should be clearly emphasized that the equal treatment of own costs of energy producers and external costs caused by the emission of gaseous pollutants - and there is no economic justification for not doing so - is crucial for the correct investment (allocation) decisions in the energy sector. As has been shown, overproduction of energy or - to be more precise - excessive pollution is socially undesirable. A change of the structure of energy production towards the greater use of renewable technologies, enabling the reduction of negative environmental and social effects, should be a reasonable and acceptable objective of EU environmental policy. Therefore the unavoidable increase in energy prices should be fully justified, and its criticism results from a lack of knowledge. People paying more for energy can, of course only partly, avoid such undesirable social costs as premature death, heart and respiratory diseases, economic losses caused by acid rain, and the global warming effects. In the case of appropriate economic calculations such a strategy is simply less expensive. Nevertheless, other energy price growth factors such as expensive energy sources, market monopolization, ignoring technological progress in exploitation of renewables, etc. may be important obstacles in implementing this strategy. That is why the pressure from the industrial lobby, unilaterally assessing the effects of such a policy, seriously hinders or even prevents its full implementation.

The cost-benefit approach is a tool that allows to set such goals, including total emission ceilings or shared use of renewable energy sources (RES) in the energy mix. Economists, however, encounter many difficulties, mainly in the correct (and not controversial) estimation of the external costs caused by the emission of gaseous pollutants. The research activities and efforts in this area are particularly complicated and interdisciplinary, and the result is highly uncertain. In addition, the uncertainty of the regulator in terms of the second element of the analysis - the lack of knowledge about the costs of preventive actions - overlaps. As a consequence, the existing economic instruments such as the emissions trading scheme, are not working properly. The EU ETS strongly differs from the original one created in the USA, primarily because of its complexity. When one adds a number of legal solutions operating in the same energy sectors (BAT requirements, RES and energy efficiency limits, technological standards, etc.), then it is possible to draw a conclusion about their doubtful environmental effectiveness and efficiency. This in turn is a vital argument to formulate critical judgments about this instrument not only by energy companies, but also by the authorities responsible for planning and conducting environmental policy. 


\section{Bibliography}

Abrell J., Ndoye Faye A., Zachmann G., 2011, Assessing the Impact of the EU ETS Using Firm Level Data, Brueger Working Paper 08.

Alberola E., Chevallier J., Chèze B., 2009, Emissions compliances and carbon prices under the EU ETS: a country specific analysis of industrial sectors, Journal of Policy Modeling, vol. 31, issue 3, pp. 446-462.

Baumol W.J., Oates W.E., 1988, The Theory of Environmental Policy, 2nd ed., Cambridge University Press, Cambridge.

Bonentia F., Oggionia G., Allevia E., Marangoni G., 2013, Evaluating the EU ETS impacts on profits, investments and prices of the Italian electricity market, Energy Policy, vol. 59, pp. 242-256.

Clo S., 2009, The effectiveness of the EU Emissions Trading Scheme, Climate Policy, vol. 9, issue 3.

Conga R., Weib M., 2010, Potential impact of (CET) carbon emissions trading on China's power sector: A perspective from different allowance allocation options, Energy, volume 35, issue 9, pp. 3921-3931.

De Bruyn S., Nelissen D., Korteland M., Davidson M., Faber J., van de Vreede G., 2008, Impacts on competitiveness from EU ETS: An analysis of the Dutch industry, CE Delft Report, The Netherlands.

Egenhofer C., Alessi M., Georgiev A., Fujiwara N., 2011, The EU Emissions Trading System and Climate Policy Towards 2050. Real Incentives to Reduce Emissions and Drive Innovation?, Centre for European Policy Studies, Brussels.

Ellerman A.D., Convery F.J., Perthuis C., 2010, Pricing Carbon: The European Union Emissions Trading Scheme, Cambridge University Press, Cambridge.

Faure M., Peeters M., 2008, Climate Change and European Emissions Trading: Lessons for Theory and Practice, Edward Elgar.

Grubb M., Laing T., Sato M., Comberti C., 2012, Analyses of the effectiveness of trading in EU ETS, Climate Strategies Working Paper.

Helm D., 2005, Economic instruments and environmental policy, The Economic and Social Review, vol. 36 , no. 3 .

Hoffmann V., 2007, EU ETS and investment decisions: the case of the german electricity industry, European Management Journal, vol. 25, issue 6, pp. 464-474.

Kirat D., Ahamada I., 2011, The impact of the European Union emission trading scheme on the electricity-generation sector, Energy Economics, vol. 33, issue 5, pp. 995-1003.

Laing T., Sato M., Grubb M., Comberti C., 2013, Assessing the effectiveness of the EU Emissions Trading System, Centre for Climate Change Economics and Policy Working Paper No. 126.

Linares P., Santos F., Ventosa M., Lapiedra L., 2006, Impacts of the European emissions trading scheme directive and permit assignment methods on the Spanish electricity sector, The Energy Journal, vol. 27 , no. 1, pp. 79-98.

Lund P., 2007, Impacts of EU carbon emission trade directive on energy-intensive industries - Indicative micro-economic analyses, Ecological Economics, vol. 63, issue 4, pp. 799-806.

Martin R., Muûls M., Wagner U., 2012, An evidence review of the EU Emissions Trading System, focusing on effectiveness of the system in driving industrial abatement, Energy and Climate Change.

Opschoor J.B., Vos H.B., 1989, Economic Instruments for Environmental Protection, OECD Publications Service, Paris.

Pearce D., Turner K., 1990, Economics of Natural Resources and the Environment, Harvester Whateshaw, London.

Rogge K., Hoffmann V., 2010, The impact of the EU ETS on the sectoral innovation system for power generation technologies - Findings for Germany, Energy Policy, vol. 38, issue 12, pp. 7639-7652. 
The impact of a $\mathrm{CO}_{2}$ levy on the electricity sector, 2016, ECOFYS.

Thema J., Suerkemper F., Grave K., Amelung A., 2013, The impact of electricity demand reduction policies on the EU-ETS: Modelling electricity and carbon prices and the effect on industrial competitiveness, Energy Policy, volume 60, pp. 656-666.

Tietenberg T., 1991, Economic Instruments for Environmental Regulation, [in:] D.R. Helm (ed.), Economic Policy towards the Environment, Blackwell, Oxford.

Villoria-Sáeza P., Tamb W.Y., del Río Merinoa M., Arrebolaa C.V., Wang X., 2016, Effectiveness of greenhouse gas emission trading schemes implementation: a review on legislations, Journal of Cleaner Production, vol. 127.

Weitzman M., 1974, Prices vs quantities, Review of Economic Studies, vol. 41. 